\title{
Evaluating Self-access Learning in Online Resource-based Context
}

\author{
Wen-wen Cheng \\ Language Center, National Kaohsiung University of Applied Sciences, Taiwan \\ 415, Jiangong Rd., Sanmin Dist., Kaohsiung City 807, Taiwan \\ Tel: 886-935-856-426 E-mail: wliebe@gmail.com \\ Su-ching Lin (corresponding author) \\ Dept. of Education, National Changhua University of Education, Taiwan \\ 1, Jin De Road, Paisha Village, Changhua City, Changhua County 500, Taiwan \\ Tel: 886-919-089-047Ｅ-mail:sclin@cc.ncue.edu.tw
}

\begin{abstract}
Ming-sui $\mathrm{Wu}$
Dept. of Applied Japanese, Ming-Chuan University, Taiwan

5, De Ming Rd.,Gui Shan District, Taoyuan City 333, Taiwan

Tel: 886-919-932-793 E-mail: mswu@mail.mcu.edu.tw
\end{abstract}

Received: September 1, 2015 Accepted: October 25, 2015 Published: November 2, 2015

doi: $10.5296 /$ jsss.v3i1.8238

URL: http://dx.doi.org/10.5296/jsss.v3i1.8238

\begin{abstract}
For the past two decades, language center in almost every university in Taiwan has attempted to implement the notion of independent learning through online learning resources. To many student learners, the easy and inexpensive access of Internet has made innumerable learning resources provided by language centers available for self-access language learning. However, whether students have cultivated self-access learning ability through appropriate learning practices online is the main point that school authorities are eager to find out. In order to
\end{abstract}


know the effectiveness of self-access learning in online resource-based context, many universities take different ways to evaluate students' achievement. Since evaluations of self-access learning are important for student learners to know if they gradually and individually move towards autonomy, their assessments must be more objective. The purpose of this one-year study, therefore, was to examine whether selected online learning resources and evaluation methods affected students' self-access learning attitudes and whether students cultivated self-access learning ability and learned successfully in online resource-based context. To gather the data, one hundred and twelve non-English majored students from a university of Southern Taiwan were recruited as samples and two types of objective evaluation, an assessment test and online learning records, were used in this study. Major findings indicated that language students' self-access learning attitudes improved and they did make progress in online resource-based context. However, the training for students toward self-access learning needs to be strengthened. Suggestions were also included in this paper.

Keywords: Self-access learning, On-line resource-based, Evaluation

\section{Introduction}

In recent years, language centers in many universities provide various online learning resources to encourage self-access language learning and the modes of learning have become an integral part of ESL courses to promote linguistic skills. According to some researchers, online learning environment provides a variety of advantages with "sheltered learning environment" at their own pace without "experiencing intense feelings of anxiety" (Pino, 2008). The online learning materials are also found to be helpful in creating the encouraging environment in many studies (Aydin, 2007; Son, 2008; Thomson, 2010). The resource-based approaches offer learners the opportunities to develop greater control over their own individual learning in the most effective way: the learning plans, the selection of learning materials and the evaluation of learning (Benson, 2001). Whether language learners choose suitable learning materials is a question. As Sturtridge mentioned (1997), learning materials are one of the key factors that affect the effectiveness of self-access: if the materials appropriate to self-access learning and if the range and arrangement of materials are suitable. When it comes to online learning resources, many will think of diverse materials such as text, images, videos, and audio. Although some researchers may think learners should select their own learning materials according to their needs, students tend to choose the materials recommended by their teachers (Macdonald-Smith, cited in Benson \& Voller, 1997). In this study, the online learning materials, E-touch learning system, were selected and arranged by language center.

Theoretically speaking, there are no assessment constraints to be placed on self-access learners and they are allowed to develop their learning interests completely autonomously (Garner \& Miller, 1999). However, students need proof of academic achievement. Therefore, majority of the universities try to integrate the online resource-based learning as part of the performance into their academic record and set some rules for evaluating their achievement. Some universities, then, collect the learning records from online learning system for the 
evidence of self-access learning. In this study, to examine whether appropriate learning practices occurred in self-access learning and the time students spent on doing the online tests or exercises, the scores were recorded by the systems and counted as part of the term grades for each semester. According to Garner and Miller (1999), the need of keeping a portfolio is "to collect evidence of their achievements over a period of time". Through the learning portfolio for the best picture of learning process, teachers had better understanding about students' learning behavior and their motivation. In addition to the online records used to evaluate students' performance of self-access, a paper-based comprehensive assessment was imposed on the students to see whether self-access facilitates learning.

In Satoko and Sugawara's (2012) point of view, simply focusing on language learning is not enough to promote learner independency. To equip student learners with skills to manage and control their own learning is essential (Benson, 2011). Since language center of this study has implemented the paper-based assessment and keeping online learning portfolio for self-access learning under the school policy for a long time, the researcher would like to know the implementation and results of self-access learning in online resource-based context. Thus, this study was to investigate the following research questions:

1). Do students improve their self-access learning ability after learning the arranged online learning materials?

2). Do students learn successfully in online resource-based context?

\section{Methodology}

The data collection instrument of previous studies about evaluating self-access learning was mostly through a questionnaire survey. In order to get concrete evaluation and evidence to prove students' achievement, in this study, two types of objective evaluation were used to make sure if students had made progress and developed the ability to study independently. Under the school policy, the sophomores had to finish three assigned on-line General English Proficiency Test (GEPT) entitled GEPT 1, GEPT 2 and GEPT 3 on E-touch learning system before deadline during the semester. Then an assessment test designed by language center based on the three assigned online GEPT tests was conducted before the end of the semester. The score of the assessment test constituted $10 \%$ of the General English (GE) class final grade. Three another practices entitled Pre-assessment Preparation 1, 2 and 3 (PreA 1, 2, 3) were also listed on E-touch learning system without informing the students before the assessment. Furthermore, in order to encourage students to cultivate self-access learning ability, language center offered a variety of English learning activities and online learning resources to the students. Maximum 10 bonus points were added to daily performance marks depending on the time they spent on online learning and activities they joined, basically one point for a complete hour of learning. In this study, the researcher focused on examining the part of online learning record for one academic year. With the paper-based assessment and flexible learning records online, students' self-access learning behaviors and achievement were clearly viewed. 


\subsection{Participants}

The student participants for this study were selected from two Intermediate level of General English classes (GE) from College of Business and College of Information at a university of Southern Taiwan from the fall of 2013 to the spring of 2014, including Department of Trade, Department of Finance, Department of International Business Management, Department of Information Technology and Communication, Department of Accounting Information Systems, Department of Marketing Management and Department of Computer Simulation and Design. In total, 112 students were selected to participate in this survey, but two of the participants dropped out of the class in the spring of 2014, resulting in the total participants as 110.

\subsection{Statistical Procedures}

In order to analyze whether students made progress in online resource-based context and improved their attitudes toward self-access learning, descriptive statistics and bar graph were used to summarize data. Specifically, the gathered data were computed and tabulated by application of Microsoft Excel 2010. The counts for each assigned GEPT test and the Pre-assessment Preparation were added up and showed the percentages for each semester, the fall of 2013 and the spring of 2014. Furthermore, the scores for 50-question assessment with 2 points for each question were marked and divided into ten groups ranging for 10 points for each group from lowest to the highest scores. Finally, the numbers of students who got the bonus points for online self-access learning in the fall of 2013 and the spring of 2014 were also counted.

\section{Findings}

The first research question examined whether students' attitudes toward self-access learning improved. The statistics outlined in Table 1 showed that in the fall of 2013, none of the participants, that was $51.9 \%$ of them did the three assigned online GEPT1, 2, and 3 tests, while $22.3 \%$ of them did PreA 1, 14.2\% of them did PreA 2 and equal percentage of students $11.6 \%$ did PreA 3 .

Table 1. Participants who did the online three assigned GEPT exercises and pre-assessment exercises in the fall of 2013

\begin{tabular}{lll}
\hline Test & Number & Percentage \\
\hline GEPT 1 & 0 & 0 \\
GEPT 2 & 0 & 0 \\
GEPT 3 & 0 & 0 \\
PreA 1 & 25 & $22.3 \%$ \\
PreA 2 & 16 & $14.2 \%$ \\
PreA 3 & 13 & $11.6 \%$ \\
\hline
\end{tabular}

$N=112$. 


\section{Macrothink}

Journal of Social Science Studies

ISSN 2329-9150 2016, Vol. 3, No. 1

As to the three assigned online GEPT tests and the Pre-assessment Preparation exercises in the spring of 2014, showed as Table 2. 11.8\% of the participants in both GEPT 1 and GEPT 2, and $0.9 \%$ of them in GEPT 3 practiced online as required. With percentage of $22.7 \%, 16.4$ and $15.5 \%$ in PreA 1, PreA 2 and PreA 3 respectively, students seemed to prefer Pre-assessment Preparation exercises to assigned GEPT tests for reviewing the coverage of assessment.

Table 2. Participants who did the online three assigned GEPT exercises and pre-assessment exercises in the spring of 2014

\begin{tabular}{lll}
\hline Test & Number & Percentage \\
\hline GEPT 1 & 2 & $1.8 \%$ \\
GEPT 2 & 2 & $1.8 \%$ \\
GEPT 3 & 1 & $0.9 \%$ \\
PreA 1 & 25 & $22.7 \%$ \\
PreA 2 & 18 & $16.4 \%$ \\
PreA 3 & 17 & $15.5 \%$ \\
\hline
\end{tabular}

$N=110$.

The comparison between participants who got bonus points in the fall of 2013 and the spring of 2014 was shown in Table 3. The number of students, 17, who got bonus points for online self-access learning in the spring of 2014 was larger than the number, 12, in the fall of 2013. It means more students were willing to access the online learning resources and got the bonus points. 


\section{Macrothink}

Journal of Social Science Studies

ISSN 2329-9150

2016, Vol. 3, No. 1

Table 3. Students who got bonus points for online self-access learning in the fall of 2013 and in the spring of 2014

\begin{tabular}{lll}
\hline $\begin{array}{l}\text { Academic Year } \\
\text { Bonus points }\end{array}$ & Fall of 2013 & Spring of 2014 \\
\hline 1 point & 6 & 5 \\
2 points & 4 & 7 \\
3 points & 0 & 2 \\
4 points & 1 & 0 \\
5 points & 0 & 1 \\
6 points & 0 & 0 \\
7 points & 0 & 0 \\
8 points & 1 & 1 \\
9 points & 0 & 0 \\
10 points & 0 & 1 \\
\hline Total & 12 & 17 \\
\hline Percentage & $10.7 \%$ & $15.4 \%$ \\
\hline
\end{tabular}

$\mathrm{N}=112$ (fall of 2013), $\quad \mathrm{N}=110$ (spring of 2014).

Table 4. Student participants' scores of assessment test in the fall of 2013

\begin{tabular}{ll}
\hline Score & Number \\
\hline $0-10$ & 0 \\
$11-20$ & 1 \\
$21-30$ & 12 \\
$31-40$ & 39 \\
$41-50$ & 30 \\
$51-60$ & 10 \\
$61-70$ & 3 \\
$71-80$ & 3 \\
$81-90$ & 3 \\
$91-100$ & 2 \\
\hline
\end{tabular}

$\mathrm{N}=103$ (nine participants were absent for the assessment test).

The second research question addressed whether students made progress in online 


\section{Macrothink}

Journal of Social Science Studies

ISSN 2329-9150

2016, Vol. 3, No. 1

resource-based context. Table 4 and 5 summarized the participants' scores of assessment test in the fall of 2013 and the spring of 2014. In order to compare the scores in these two semesters and see clearly if students' performance improved, the researcher showed the combined data below in Figure 1.

Table 5. Participants' scores of assessment test in the spring of 2014

\begin{tabular}{ll}
\hline Score & Number \\
\hline $0-10$ & 0 \\
$11-20$ & 2 \\
$21-30$ & 5 \\
$31-40$ & 22 \\
$41-50$ & 30 \\
$51-60$ & 25 \\
$61-70$ & 10 \\
$71-80$ & 5 \\
$81-90$ & 3 \\
$91-100$ & 0 \\
\hline
\end{tabular}

$\mathrm{N}=103$ (seven participants were absent for the assessment test).

The bar graph of Figure 1 with the scores appearing along the horizontal axis and the height of the bar corresponding to the number of the students who participated in the assessments showed clear comparison between these two assessments. The blue bar represented the fall of 2013, with red bar representing the spring of 2014. As we can see, the number of the students who got more than 60 points in the spring of 2014 was more than the number in the fall of 2013. Moreover, the numbers ranging from scores 51-60 dramatically increased in the spring of 2014. Obviously, when compared to the fall of 2013, students who got less than 40 points decreased in the spring of 2014. 


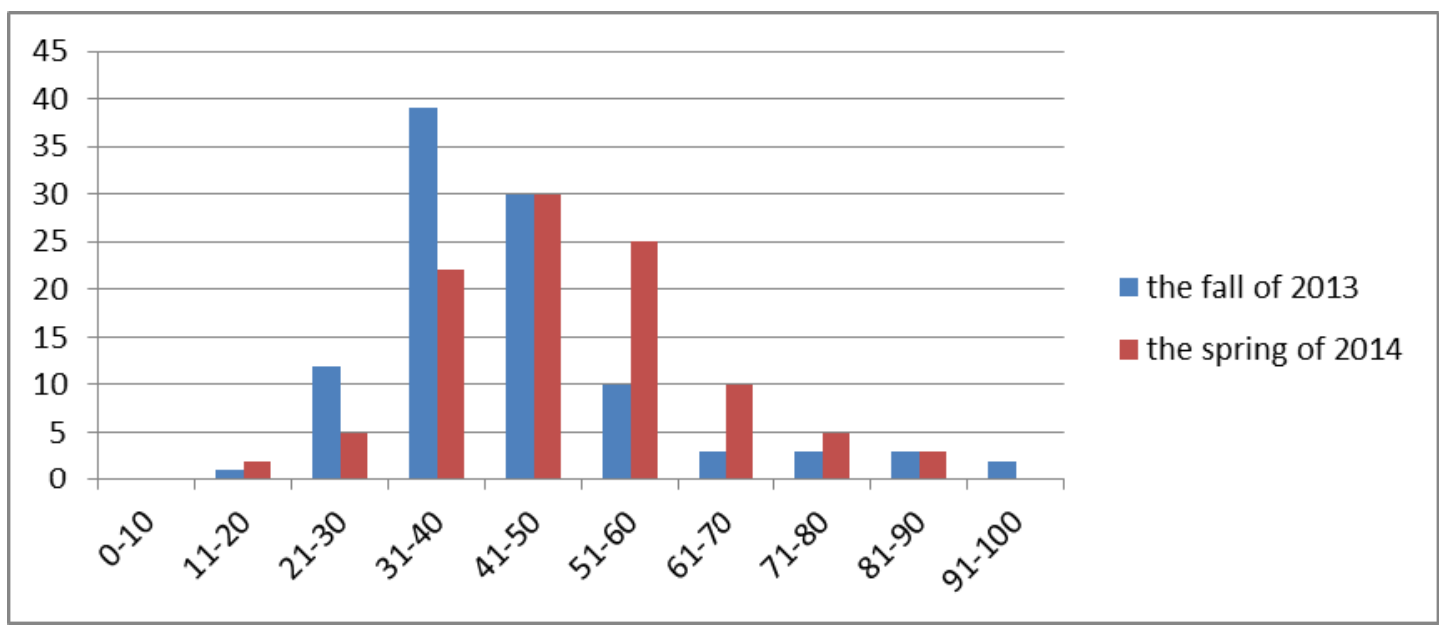

Figure 1. Comparison between the scores of assessment tests in the fall of 2013 and the spring of 2014

\section{Conclusions}

As the researcher mentioned above, to implement the notion of independent learning through online learning resources is almost the same method in many universities in Taiwan and school authorities are pressing for an inquiry into knowing students achievement. The findings of the current study showed that students' attitudes toward self-access learning improved as shown in Table 1, 2 and 3, but few of them did the regular learning practices as required. Table 1 and 2 indicated that none of the participants did the three assigned GEPT exercises before deadline in the first semester and less than $1.8 \%$ of the participants did each assigned GEPT test in the second semester. Interestingly, the fastest way for them to get a better grade for the assessment was to review the Pre-assessment Preparation exercises that were not asked to do. According to the system records, even for the Pre-assessment Preparation 1, 2, 3, students who did these exercises were mostly the same part of the students. That is, even there was an assessment constituting $10 \%$ of the General English class final grade, most students overlooked the fact. That suggests some adjustments should be made to the policy. To cut the long duration into three short periods of time according to these three assigned exercises may help the students to fulfill their mission. To elaborate, a deadline for each assigned GEPT test should be set instead of a deadline for all the assigned GEPT exercises in the first semester. After twelve weeks' training first, students might get used to the rule and learned through online resources autonomously in the second semester. To answer the second research question, students did make progress in online resource-based context as shown in Table 4, 5 and Figure 1.

Basically, most of the learning resources from E-touch learning system are test-oriented like the questions of GEPT or TOEIC. On the one hand, for students who are ambitious and competitive, doing the exercises on E-touch learning system is helpful and beneficial because they can get familiar with the test form and also get bonus points for online self-access learning. On the other hand, the test-oriented learning exercises are not so interesting for 
some students with low motivation and achievement to do self-assess learning. In order to inspire most of the students to conduct self-access learning, in addition to test-oriented exercises, different types of exercises related to the topics taught in the classroom or personal interests should be considered. Regarding bonus points, online learning resources shouldn't be limited to test-oriented exercises. Clear directions and various categories for selection will motivate students to learn. Moreover, some immediate online feedback or rewards to their performance should also be built in the learning system. Since learning in isolation, students still need some encouragement when lacking of teachers' contributions before completely independent.

To sum up, students' attitudes toward self-access learning improved, but there's still a lot to do about online learning resources and learner training. Although self-access learning does not ensure learner independence, it increases the awareness of the learners and their willingness and ability to manage their own learning (Sheerin, 1997). When students have a clearer idea about self-access learning and knowing what their objectives are, their achievement will be more obvious. The researcher hopes that the findings of the study can offer school authorities and language centers some suggestions when setting related self-access language learning policy.

\section{Acknowledgement}

The authors would like to thank the Ministry of Science and Technology, Taiwan for financially supporting this research under Contract No. MOST104-2410-H-018-020

\section{References}

Aydin, S. (2007). Attitudes of EFL learners towards the internet. The Turkish Online Journal of Educational Technology, 6(3), article 2.

Benson, P. (2001). Teaching and Researching Autonomy in Language Learning. London: Longman.

Benson, P. (2011). Teaching and researching autonomy (second edition). London: Longman.

Benson, P. \& Voller, P. (1997). Autonomy \& Independence in Language Learning. London: Longman.

Gardner, D., \& Miller, L. (1999). Establishing Self-Access : From Theory to Practice. Cambridge: Cambridge University Press.

Kato, S., \& Sugawara, H. (Forthcoming 2012). Eigo gakushuu techo 2013. (English language learning planner 2013) Chiba: Kanda Gaigo Daigaku Shuppan Kyoku.

Pino, D. (2008). Web-based English as L2 instruction and learning: Strength and Weakness. Retrieved from http://findarticles.com/p/articles/mi_hb5835/is_200803/ai_n32281702/

Sheerin, S. (1997). 'An exploration of the relationship between self-access and independent learning'. In P. Benson, \& P. Voller (Eds.), Autonomy and Independence in Language Learning (pp. 54-65). London: Longman. 


\section{Macrothink}

Journal of Social Science Studies

ISSN 2329-9150 2016, Vol. 3, No. 1

Son, J-B. (2008). Using web-based language learning activities in the ESL classroom. Journal Of Pedagogies and Learning, 4(4), 34-43. http://dx.doi.org/10.5172/ijpl.4.4.34

Thomson, L. D. (2010). Beyond the classroom walls: Teachers and students perspective on how online learning can meet the needs of gifted students. Journal of Advanced Academic, 21(4), 622-712. http://dx.doi.org/10.1177/1932202x1002100405

Zarlina, M. Z., Airil, H. M. A., Sheema, L. I., \& Johana, Y. (2012). Students' Perception of Using Online Language Learning Materials. Procedia - Social and Behavioral Sciences, 67, 611-620. http://dx.doi.org/10.1016/j.sbspro.2012.11.367

\section{Copyright Disclaimer}

Copyright reserved by the author(s).

This article is an open-access article distributed under the terms and conditions of the Creative Commons Attribution license (http://creativecommons.org/licenses/by/3.0/). 